\title{
Performance Management Practices And Its Impact On Banks' Performance In Pakistan
}

\author{
Ayesha Yaseen (MS Scholar) \\ Department of Management Sciences, The Islamia University of Bahawalpur \\ Email: Ayesha_ayesha12@hotmail.com
}

Doi:10.5296/ ijhrs.v5i4.8821 URL: http://dx.doi.org/10.5296/ ijhrs.v5i4.8821

\begin{abstract}
Purpose-This descriptive research analysis the best performance management practice and its impact on employee motivation, loyalty, efficiency and effectiveness in banking sector of Pakistan and suggesting new methods for improving their performance management systems.

Design/ Methodology-Researchers have used the qualitative research methodology in which Content Analysis technique is being used to interpret data. Questionnaire and Semi structured Interviews were also conducted from the middle management according to the needs and purpose of the research.

Findings- Research findings show that there is a positive relationship between Loyalty, Motivation and Effectiveness with true Performance Management Systems. Analysis of the data also shows that absence of guidance and feedback in current appraisal system leads to dissatisfaction amongst employees.

Practical implications- Current research may be used by HR managers to identify and improve performance management systems to develop employee motivation and loyalty as well as they can build trust, believe in and support the current performance process by implicating new suggestions and solutions. It also provides the literature for future researches.
\end{abstract}

Keywords: Performance management, Appraisal, Motivation, Loyalty, Support, Efficiency and Productivity. 


\section{Introduction}

Every financial institution in the world wants to become world-class in their quality of products and service delivery by legal ways. They want to deliver better services and products at a low cost to compete well and penetrate in a country for that they are working hard. They have realized that they can gain competitive advantage by the Knowledge and skills of their employees. In order to get business success and competitive advantage they are so much concerned about satisfying and motivating their employees. This fact introduces the concept and need of effective Performance Management System.

Performance management can be viewed as a proactive system of administration of employee performance for motivating the individuals and the organizations towards desired performance and results. It's about striking a synergic alignment among individual and organizational objectives for achievement of excellence in performance. Activities such as joint goal setting, continuous progress review followed by frequent communication, comments and coaching for improved performance, execution of employee advancement programs and rewarding accomplishments. The process of performance management begins with the joining of a new employee in an organization and ends when that employee quits the organization. Performance management consists of performance appraisal and performance development. Performance appraisal is one of the most widely used techniques of guarantying the value of employee performance. The achievement of performance appraisal depends on how effectively and efficiently it is implemented. It also depends on understanding of employee about the performance appraisal system and how positively employees are oriented towards their system.

The first part of the paper analyzes various practices about PM systems in banking sector but the best one that is going to adopt or adapt is eventually decided by the firm and second part of the paper focus on the use of performance management- an increasingly popular human resource intervention- as a mean to improve motivation and employee loyalty, support and believe. The aim of this paper is to observe the effect of performance management on the reward, motivation job satisfaction, which will finally guide to success of the banks. It further throws light to recommend suggestive solutions that can increase effectiveness of the performance management system of Pakistani banks.

\section{Literature Review}

This paper will probe into the supporting literature of performance management systems and its importance. Furthermore, this research study will stick the significance of banking industry and usage of different performance appraisal systems and what is the linkage of motivation, job satisfaction and employee loyalty, support and believe in the current performance appraisal process and organizational success moreover will give suggestions to improve performance management systems. 


\section{Macrothink \\ International Journal of Human Resource Studies \\ ISSN 2162-3058 2015, Vol. 5, No. 4}

\section{Performance management systems: Performance management}

Performance management is a set of actions and assessments that ensure the company is being effective and efficient in the process of achieving its goals. Performance management systems are the "Achilles' heel" of human resources management, which typically include:

a.performance appraisal

b. Employee development

\section{Performance appraisal;}

It is the particular evaluation of the performance of employees inside the company. Performance appraisal has following features:

- Operational

- Short to mid-run goals

- Retrospective

- Episodic

- Systematic

- Isolated from business needs

- Management by command

- Individualistic

- Human resource owned

- Rigid and inflexible

- Focus on mistakes, misbehaviors

- Bureaucratic

- Superficial

- Focus on quantitative aspect of performance

- Linked with financial rewards

(Rosario, longo: 2011) Primarily, a performance management system includes two elements.

That is people and process

Process:

Process includes items such as:

- $\quad$ Rating criteria.

- The time duration of performance appraisal discussions. 


\section{Macrothink}

- Reward and appreciation systems.

- Job description.

People:

The key component of the people element includes:

- Manager, who drives the system by setting expectations,

- Communicating plans

- Encouraging development

- $\quad$ Feedback

Armstrong (2001: 469) suggests that performance management has a number of aims: Performance management is about getting favorable outcomes from the institute, teams and individuals by understanding and organizing performance within an agreed framework of already set goals, standards and competing requirements. It is a course of action for developing shared understanding about what and how is to be achieved, and an approach to organization and developing people in a way which increases the probability that it will be achieved in the short and long term.

\section{Key attributes of performance management:}

Owned and managed by management. Strategic,

Long run goals, looking forward, Constant, Integrated,

Management by agreement, Holistic,

Managers owned, Supple and adaptable,

Focus on individuals growth, Practical and effective, Qualitative phase of performance,

(Rosario, Longo: 2011)

\section{Importance of performance Management:}

Performance Management Practices is now modified as performance management study. It plays an important role in the development of an organization and performance management is a critical business tool in interpreting strategy into results. Results in terms of staff members believe in and support, employee motivation, employee loyalty and organizational success within banking sector of Pakistan.

Performance management system has a direct impact on five critical organizational outcomes: financial performance, product or service quality, productivity, customer satisfaction, and employee job contentment. The effectiveness of the performance management is recognized as the achievement of both financial and non-financial objectives, the development of skills and abilities, and the Improvement of customer care and quality of process (de Waal, 2007, p. 120). Skills and abilities of employees are improved by the provision of training and 
development as performance appraisal will clarify the areas where one needs improvement and appreciating areas of remarkable performance by rewarding them. Selection of Performance Appraisal systems is the key part of the performance Management .A company might have a world-class performance management system in place, but the system is only as effective when it is implemented effectively by managers. Organizations that want to increase organizational and employee performance and productivity should invest in getting the right managers in place and support them in engaging their employees at the right time. It also helps management to ensure progress towards strategic goals (Langfield-Smith, 1997). As performance management helps in fulfilling strategic goals thus organization moves ahead directed towards its success and prosperity. Individuals to see their part in the wider enterprise they start identifying themselves with organization with greater job clarity and responsibilities (Williams, 1998). When employees get motivated, obvious about their job responsibilities, task and sure about progression opportunities they work hard for organization's success. Organization should present true and fair image of performance appraisal to build trust, confidence and support of the employee toward organization, their loyalty and job satisfaction are the foremost fundamentals of any organizational success (Robinson\& Rousseau, 1994). Truthful appraisal can reduce inequalities, injustice and corruption employees will be sure that if they will work hard, will be rewarded and they will get motivated thus enhance production of an organization. "Performance appraisal is an organizational coordination that includes planned processes for shaping staff activities so that staff value effectiveness and efficiency can be (Winston \& Creamer, 1997).

Organizations get to know the importance of performance appraisal as they evident the enhanced productivity of employees of all big multinational companies that they have implemented the performance appraisal and the importance of performance management and its measurement has been cleared by different viewpoints (Whitney, 1994).

\section{Objective of performance appraisal:}

The purpose of performance appraisal is to influence the employee's job performance in a progressive way with an organized process appraisal, and get to know the major impacts on the employees to get the certain level of motivation to improve the productivity of the organization as well as the job satisfaction and loyalty (Natalie \& Ann 2005). The following objectives of performance appraisal policies have been identified (Winston \& Craemer, 1997): enhance motivation to carry out tasks effectively and effectively increases personnel feeling of pride Gain new and clear perception into staff and supervisors to control the organization targets depending upon the performance of employees clarify and define job functions, all information and responsibilities regarding the task which are required from the employees develop productive and constructive communication and feedback among appraisal as it will remove the complaints of employees about the function of organization, if have any encourage increased self-understanding among staff as well as clear understanding of the development activities that are of value or worth. This process also allows the employees to get the proper training and orientation of skills where they are lacking as it identifies the strengths and weaknesses of employees and also suggests the various improvement plans by 
the management after performance appraisal process distribute rewards on a fair and credible basis and recognition after reviewing the performance of employees over the period of time. This review of performance, evaluator judges the actual performance with the targeted performance standards and benchmarks.

\section{History of performance appraisal:}

Performance appraisal in the beginning was just the way to reduce inequalities and injustice in monetary terms as it used to ensure whether employee is paid according to its worth it had nothing to do with employees feelings or appreciation then this concept was modified into a multidimensional approach, to align employee performance with organization strategy and which led to the start of performance management (Franzsen, 2003: 133). In early days, appraisal systems had different meanings in diverse circumstances. For example, it could be used to evaluate or audit individuals, as a tool for succession planning, training, controlling, development and motivation. Managers were not equipped or empowered to use appraisals as a management tool and employees did not see the benefit of this tool for themselves. Over time, performance management has become a management tool to ensure effectiveness and alignment of individual and organization goals/objectives (Shelley, 1999: 442-443).

\section{Performance management in financial institutions:}

"Performance Appraisal" is a mean to

(1)Authenticate and refine organizational actions (e.g. selection, Training); and

(2)Present feedback to employees with an eye on improving future performance.

Following steps should keep in the mind in the effective Performance appraisal in banking sector:

1. Select what performance data to collect

2. Determine who conducts the appraisal

3. Decide on a rating philosophy

4. Overcome rating deficiencies

5. Create a rating instrument

Deliver useful information to employees 


\section{Background and Basis of performance management in banking sector:}

When banks were small in size formal performance appraisal system was just to make decisions about salaries, promotions, transfers and placements on the basis of personal knowledge and were centralized by time dispersion of branches, staff and with the swift expansion in number of branches executives who used to make decisions had very limited personal knowledge. He had to rely on performance appraisal reports. Banking struggles by innovating and enhancing the key competencies of their Human s employees. The human resource system can be made successful by having a suitable appraisal system that also acts as a flawless motivator.

Chowdhury (2008), banking services is one sector where a great Level of importance of Performance Appraisal Systems is being identified. Several of the public sector banks (PSBs) have changed their PAS or are in the process of changing them. Y. Zhang (2009) suggested that in Chinese state-owned banking industry, employees' perception of justice and equality has a positive relationship to their overall satisfaction with both the performance appraisal process and its truthful results. However, statistically significant differences were found in relation to whether employees had received training in performance appraisal or not as it presents flaws or untrue results.

\section{Diverse Performance Management practices:}

There are different systems and methods for measuring performance and apprising the employees' one of traditional and modern method.

\section{Traditional Methods:}

In the conventional methods there are mixtures of systems to measure the performance employees.

\section{Appraise Employees with Behaviorally Anchored Rating Scales:}

The traditional method of measurement Behaviorally Anchored Rating Scale is widely used by many organizations across the globe. In this system it focuses on specific behaviors, either affective or ineffective performance is given by the employee Instead of relying on behaviors that can be appraised in any position in a company, the BARS method bases evaluations on specific behaviors required for each individual position in an individual company .It involves The critical incidents technique that can be defined as a set of measures that can thoroughly pinpoint key behaviors that contribute to success or failure of individuals or organizations in particular situations. Evaluators appraise the performance depending upon the critical incident and the positives and negatives behaviors in a certain time period to measure the performance (Dessler, 2000) and different combinations of rating scale.

\section{Graphic Rating Scale:}

In Graphic Rating Scale boss or assessor simples checks the different blocks in the appraisal form to measure the performance. 


\section{Essay Evaluation Method:}

In Essay Evaluation Method is a qualitative measure to appraise the employees asks the managers, supervisor and evaluators to write an essay or a descriptive note about the strength and weakness and also the overall behavior of the employees towards the job.

\section{Performance ranking Method:}

Another standing system is Performance ranking Method in which assessor or supervisor rank the performance of employee from best to worst not with the standards that has been set earlier or benchmark but it compares employees to employees.

\section{Weighted Checklist Method:}

Like other ranking and scaling methods in Weighted Checklist Method evaluator makes a checklist of all the job responsibilities and all the descriptive statements about the effective and ineffective attitude or behavior of job. As weighted method weights the narrative reports, in Paired Comparison Analysis, it weights the relative significance of the diverse options available and listed. Every choice is matched up with all the option listed (Mondy, 2008). After comparison of all option, the one with a higher weight is preferred option for the performance measurement.

\section{Forced Distribution or Forced Ranking:}

In the tradition method there is a quantitative method called Forced Distribution or Forced Ranking, it involves the percentages. In the peak group it ranked from 10 to 20 percent, middle category ranges from 70 to 80 percent and it ranked staff with worst performance 10 percent in the bottom line (Mondy, 2008).

\section{Modern Methods:}

There are diverse techniques of performance measurement in the modern times, 360 Feedback System and Management by Objectives (MBO).

There is a relationship between Performance appraisal and motivation, job satisfaction and loyalty (bonnie, 2002). It could be also use as a technique to create a completion between employees to get the job done with all the linked targets and benchmarks (Robert, 1984). It is also mandatory that employees gets the truthful performance appraisal outcome to get inspire, if the feedback of appraisal is according to their performance over the span of time that will be a great source of motivation to them they will trust, believe and support the company's current performance process. Inefficient performance can create dissatisfaction from job and ultimately can decrease the loyalty with organization. One employee always wants that evaluator recognize as well as appreciate his efforts and achievement in the professional life and also support him to dominate on his failure and give them opportunity to make advancements in his performance in future (bonnie, 2002). If the performance appraisal has some flaws in it and is actually creating some discrepancy in the procedure, then it will affect the motivation level of the workforce and ultimately it will affect their efforts and the risk taking ideas and hinders creativity and innovation for the betterment of the organization. Also 
they will lose their interest in the affairs of the organization and their motivation level will decrease (Robert \& Kim, 2007).

This de-motivation leads the employees to low level of loyalty and they will look other alternatives of good job and better opportunities (bonnie, 2002). Employees who tend to get an accurate performance appraisal over the period of time the rewards associated with that appraisal is most motivated employee among all of them and similarly he is more satisfied with job and more loyal to the organization. Therefore, the process should be fair enough as this is the critical way to motivate, satisfy employees with their job and creates the loyalty (Storey \&Sisson, 1993). Employee motivation, satisfaction and loyalty leads towards the organizational success. It will help in getting employees support and believe in current performance management process. The managers are well aware of the importance and sensitivity of performance management, and its ultimate affect on the motivation, loyalty, and job satisfaction. It has a big affect on the growth and success of the organization, so while documenting, communicating, and talking about the job particulars, they are more concerned. It has been observed that in the present time, job performance systems have much improved to get employees loyalty, but still the outcome shows that it has a negative effect on the job satisfaction and motivation of the employees if it is not appraised truly and thoroughly (Robert, 2002).If employees are demoralized and lose their loyalty, then it would have a negative effect on the aims and objectives of organization. Human resource officials use performance appraisal for decision making like planning payments and salary scale of the employees, as it helps managers in provision of training and development of employees which is needed after proper feedback.

Performance appraisal can also help the managers and leaders to decide what are the factors or major key steps should be made to increase the productivity of employees (Natalie\&Ann2005).

As performance appraisal encourages the high performers, meanwhile performance appraisal also highlights the performance that's not up to the mark and tells about the areas that needs improvements and it helps the management to remove the leaning hurdles and ambiguities thus made them get aligned with the already set objectives and aims. This system also identifies the employee who needs training and development, guidance and counseling from management to improve their performance and work on the areas where they lack at work. Organization believes that it's the best tool to monitor the level of employees and their performances and making the decision about their increments in salary, promotions, demotions and penalties (March, 1982).

\section{Keeping people motivated to get better performance:}

It has been proven (Blignaut, 2009: 14) that a motivated workforce will make the organization successful Organizations can ensure this in the following ways:

Involve employees in problem-solving; employees must become part of the solution as they will implement it in a better way when they participate and have the assurance that their suggestions are valued thus start identifying themselves as a part of the process. Treat 
employees as customers acknowledge that every individual has different needs and aspirations and should be treated differently. Ensure that new employees are a cultural fit in terms of the organization and will take time in socialization. Offer opportunities for growth and development continuously put flexible work arrangements in place, e.g. flextime, salary structure, Provide regular feedback on team and individual participation, and give clear them guidelines on task and role. Communicate regularly, openly and truthfully to tell them what they are good at and performing well and where they lack. Reward outstanding performance; recognize and appreciate in a fair and consistent way and according to their worth to the organization.

Recognize the importance of a balanced life style, stay in tune with the core family of employee so that employee make a balance in work-life and give full attention to task and targets on job. Provide employees with the support and resources as needed to do their job.

\section{Process of Performance Appraisal:}

Performance appraisal follows an organized method to appraise the employee so that it becomes rationalize and fair process for employee (Caruth \& John 2008).

It has six main areas to consider, which are:

- Performance standard

- Conveying the standard and prospect

- measuring the actual performance

- comparing the actual presentation with benchmarks

- Discussion on results

- Decision making. Performance Standard:

This is the first step in performance evaluation process. In these step smart goals, objectives are set organization wide including employees and criteria's are made to judge the employees to keep an eye on the key factors that causes any deviation from set standards. Setting up performance standards is also mandatory for the organization goals and objectives and ultimately for the productivity of business (Caruth \& John 2008).

\section{Communicating the standards and expectations:}

Next step after making the standards of performance and expected outcomes, the subsequent key part of the Performance management process is to pass on those standards to employees and train them about the achievement of the benchmarks. These standards will provide directions and guidelines and a clear path on how to meet the objectives and will make employees responsible about performance criteria and job related expectations. These standards should be conveyed at the start of the year so that employees should know what to do next time. Management can modify or edit some of standards being adaptable and proactive but employees consent will be taken by the management to do so in order to enhance the productivity.(Caruth \& John 2008). 


\section{Measuring the actual performance:}

Next step after communicating the bench marks and required performance standards to the Employee, is to observe and evaluate the performance either it's moving in a desired direction or not by keeping an eye on the tasks and job responsibility done by employees and to identify any uncertainty and set it back on track. Evaluating performance is a continuous process throughout the year and the supervisors measures the performance of employees. The choice of measuring performance method should be error free that personal grudge or biasness have no impact on the outcome of the process and help the employees rather than being troublesome for them. ( Caruth \& John 2008).

\section{Comparing the actual performance with benchmarks:}

Here, the next step is comparison of actual measured performance with the standards and benchmarks. This step is insightful as it compares targets and tasks with the standards that have been set earlier and boss should have the same opinion with the process. Comparison shows how workforce has achieved the set targets and identifies any deviations from the benchmarks. This contrast tells either the performance is according to the standards, above or below the standards. Measuring performance, evaluation, comparison and analysis are central part of this step (Caruth \& John 2008).

\section{Discussion on results:}

As in process, administration lay down some standards and communicates those benchmarks and expected performance to employees same way after getting the performance appraisal, results should be conveyed to the human resources and they should be briefed about their extra ordinary performance and the areas where they lag behind. There should be the two way feed back or meeting discussing the problems and how they can improve it but arguments should be constructive and productive with a positive attitude in order to keep the morale of employees high and to make them responsive about his performance, achievements and short falls over a span of time. This step also contains the notion of motivation and encouragement with the organization and with the job itself (Caruth \& John 2008). In this discussion, the supervisors and the subordinates discuss different problems about the present as well as the absent working skills and scenarios, career development and future plans (DYCK, 1997).

\section{Decision Making:}

The last is making the decision on the bases of results taken from the evaluation. Decision about the improvement of employees competencies, training on different tasks which are lagging behind, corrective actions to ensure effectiveness and efficiency, promotions and rise in salary, rewards, in order to provide career advancements, transfers and demotions (Caruth \& John 2008). It would help the organization to decide the measures to enhance the organizational productivity, for the recruitment and orientation process upgrading and for making training and development decisions.

The literature shows that motivation, job satisfaction and employee loyalty with organization is directly linked with the Performance Appraisal systems 


\section{Macrothink}

International Journal of Human Resource Studies

ISSN 2162-3058 2015, Vol. 5, No. 4

\section{Objectives of the study:}

1. To analyze various Performance Management practices and exploring best implementable practices which leads to effective performance management systems in Pakistani banking sector.

2. To recommend suggestive solutions that can increase effectiveness of employees

3. 3. Performance management system and to determine whether outstanding performance is rewarded.

4. 4. To explore either staff members believe and support the current performance process.

5.

6. How appraisal system interlinked with motivation and employee loyalty and organizational success within banking sector of Pakistan.

\section{Sample size and technique adopted:}

41 employees from 3 top Pakistani banks, Zarai Taraqiati bank, National bank and bank Al Habib are being used as the sample population. The technique used was convenient sampling.

\section{Data collection:}

An interview was conducted and a questionnaire was developed addressing the objectives of the study.

\section{Variables under discussion:}

\section{Different performance management practices:}

Banking sector of Pakistan is following various performance management practices and according to our questionnaire Graphic rating scale is the current performance management techniques is used said by 7\% of the respondents , QMPMS 29\%, 360 degree 7\%, narrative essay $51 \%$ and other performance based technique is used said by $12 \%$ of the respondents. It was cleared through interviews that different performance management techniques are being used in banks. 


\section{Staff member believe in and support to the current performance process:}

$76 \%$ employees are not allowed to participate in setting the standards for measuring performance while $20 \%$ said they are allowed to participate, whereas $5 \%$ are sometimes allowed to participate.

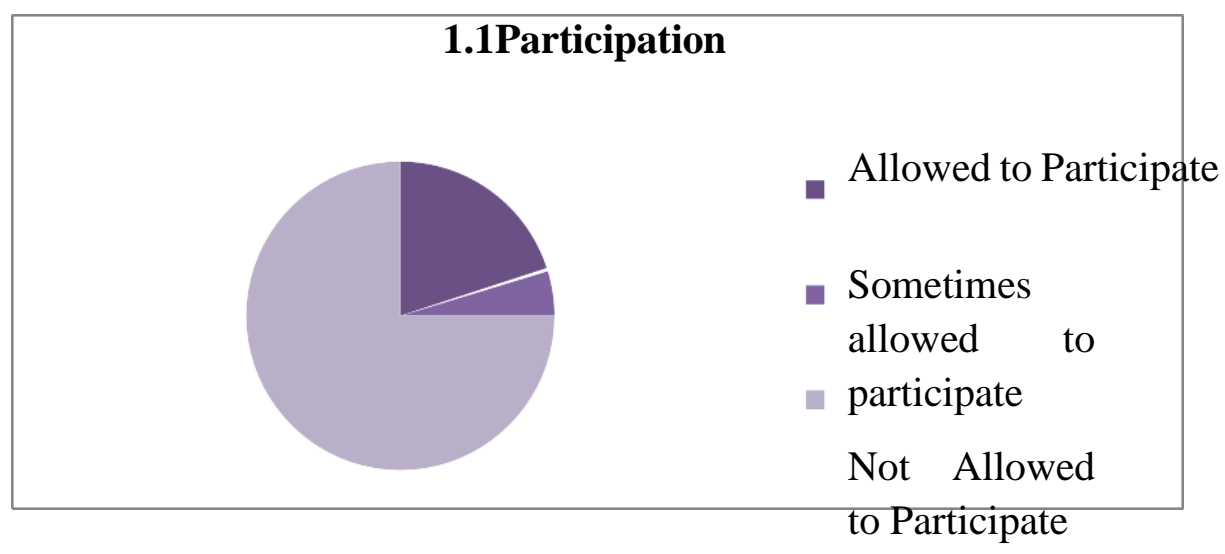

73\% people said that appraiser don't meet with each employee for discussing and planning performance appraisal process while according to $27 \%$ said they are involved in the discussions.

One of the interviewee said that they are not at all involved in setting criteria's of performance management systems.

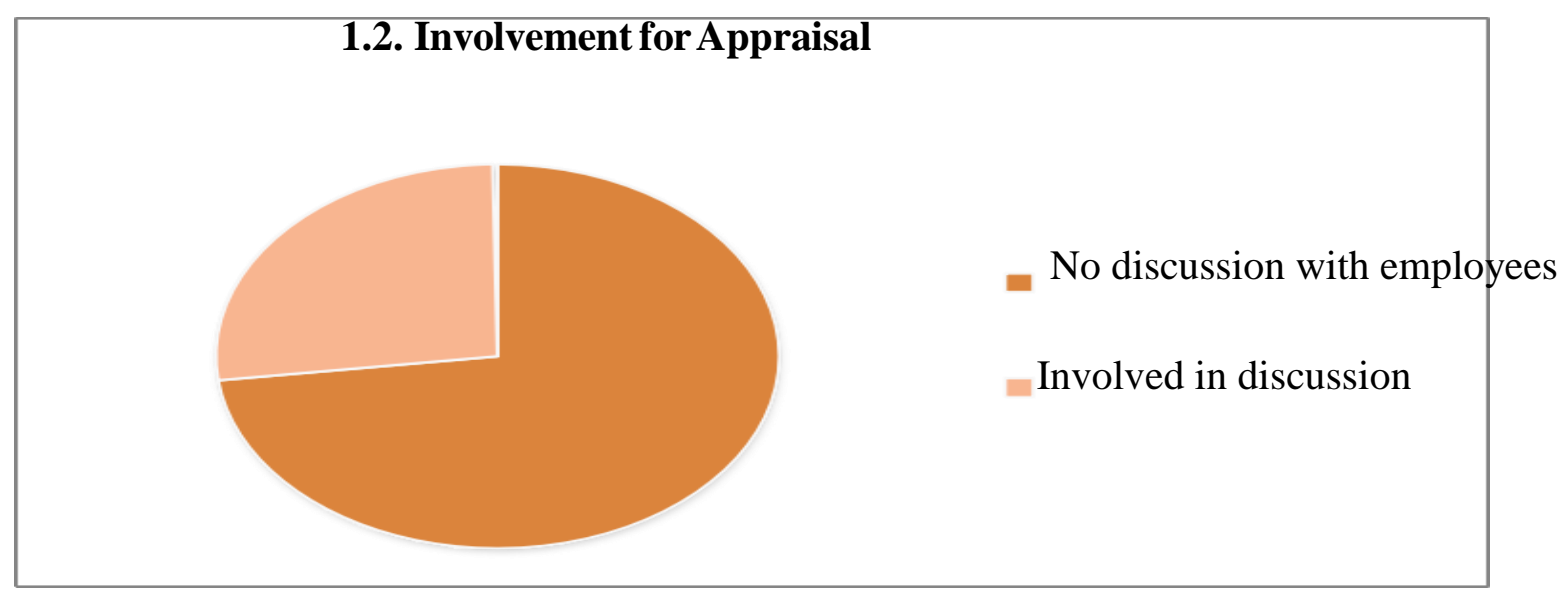

Employee motivation:

Performance appraisal program increases professional development of employees and motivating them. 


\begin{tabular}{|ll|}
\hline Strongly Agree & $19.5122 \%$ \\
\hline Agree & $65.85 \%$ \\
\hline Neutral & $10 \%$ \\
\hline Disagree & $5 \%$ \\
\hline Strongly Disagree & $0 \%$ \\
\hline
\end{tabular}

Results showed that $65.85 \%$ respondent said that they agreed with this statement that employee motivation is directly linked with true performance management systems.

\section{Efficiency and effectiveness:}

According to our survey performance appraisal has an impact on effective job performance in banks

\begin{tabular}{|ll|}
\hline Strongly Agree & $12 \%$ \\
\hline Agree & $76 \%$ \\
\hline Neutral & $7 \%$ \\
\hline Disagree & $5 \%$ \\
\hline Strongly Disagree & $0 \%$ \\
\hline
\end{tabular}

$76 \%$ of the respondents said that true performance management systems increases effectiveness and efficiency of employees.

\subsection{Performance}

Management Systems

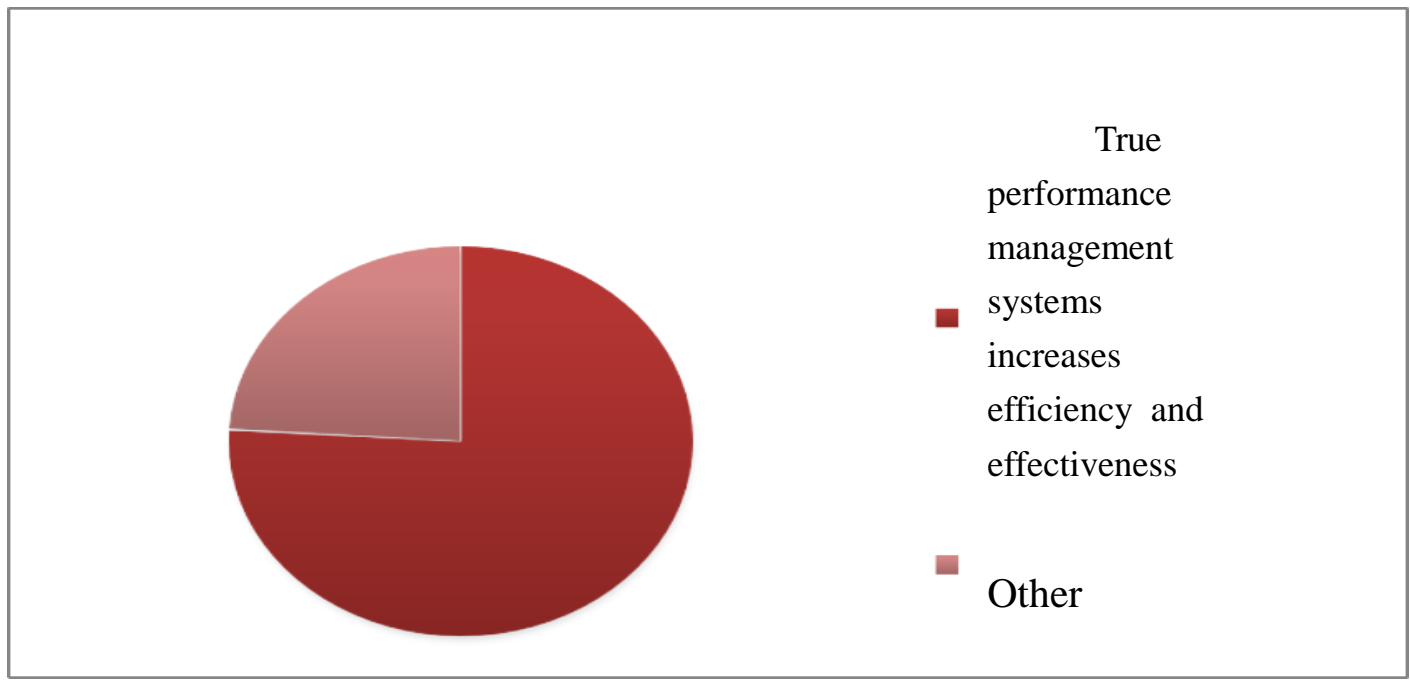




\section{Macrothink

\section{Outstanding performance is rewarded:}

According to our survey the purpose of performance appraisal is:

\begin{tabular}{|c|c|}
\hline \multicolumn{2}{|c|}{ Particulars Percentages } \\
\hline Salary Decisions & 39 \\
\hline Bonus & 61 \\
\hline Counseling & 15 \\
\hline Layoffs & 17 \\
\hline Training needs & 7 \\
\hline Promotions & 59 \\
\hline Transfers & 15 \\
\hline
\end{tabular}

$61 \%$ respondents said that the purpose of the performance appraisal is bonus and $59 \%$ said promotions so it means outstanding performance is rewarded.

\subsection{Bonus 61 and promotion 59}

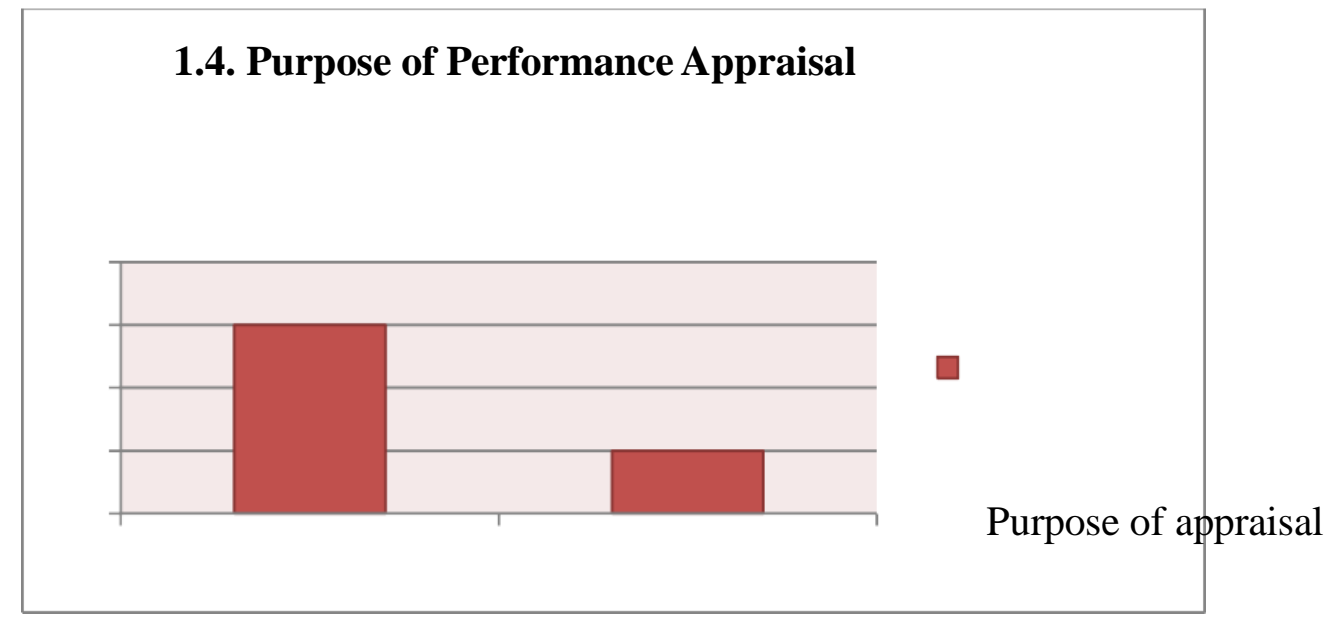

\section{Recommendations and Conclusion:}

Performance appraisal has vital importance in any organization and it is compulsory to use different performance measurement systems in an appropriate way to get true outcomes in the organization. Banking sector of Pakistan is evolving with the passage of time; by using different tools to make its operation more sophisticated it is getting better results. Result showed that there's still a room for improvement in all factors. Some of the recommendations according to the study given below: 
No hidden system or tool that overlaps or reduces the performance of any employee should be used by the organization. It is necessary that employees should know the different methods of performance measurement as the result showed that employees are unaware of performance management tool organization using exactly to appraise them and organization should let them know about the various tools of performance appraisal and educate them about those systems. Employees should know the methods of performance measurement they will be assessed or appraised on, so that they can get the idea of this process and can be prepared for it. Every appraisal system is different from other method so it should made clear that every employee is being appraised equally. Every employee should have the equal opportunities for expressing himself and his performance shouldn't remain confidential. Feedback of performance appraisal is necessary, so that an employee come to know about his capabilities \& strength and the loopholes and demerits. This will definitely improve their performance in next period of time. It can be seen that majority of the employees said that motivation, job satisfaction and employee loyal is dependent on the performance appraisal. If the employees are showing good performance then management will motivate them through some monetary and non monetary rewards, this will ultimate create the loyalty with the organization. There should be a separate board and team called externals to review the performance appraisal so that there is no chance of being prejudice and biased. Management should allow the employees to speak about the performance appraisal and tell the management whether they are satisfied with the results or not and where they are confused. Feed back of questionnaire shows that's there is strong linkage of performance appraisal with motivation, job satisfaction and employee loyalty. If the management is recognizing the efforts of employees and admiring it simultaneously management creates a loyalty image for the employee to stay with the organization. Researchers find out that Performance appraisal is conducted annually in Pakistani banks. If this process is conducted semi annually then the management is able to tell employees with reference to their strengths, weakness, their training and developmental areas, key improvement areas. So that the employees may get better by the time and they can actually perform better than the last period of performance appraisal. If the workforce of an organization is not contented with the performance appraisal, then it will ultimately negatively affect the outcome of an organization.

Hence, it's proved that there is strong relation among performance appraisal systems, motivation, and job satisfaction and employee loyalty.

\section{a. Limitations of the study:}

- All domains of performance management and outcome not investigated.

- Factors effecting performance management other than mentioned above is not collected in this study might be related to performance management.

- Different performance management practices such as training and development might positively influence performance, career advancements or developmental behavior

- Lack of comparison between the employees and managers who contributed in the 
study with the non-respondents Variables applied to different firms might give different results.

\section{References:}

Armstrong M (2001). A handbook of human resource management practice (8 ed.), Kogan Page Publisher

Blignaut, L. 2009. Motivate your employees to be star performers. Practical Guide to Human Resources Management, 14.

Cardy, R.L., Dobbins, G.H. (1994), -Performance Appraisal: Alternate Perspectives\|l, South-Western Publishing Company, Cincinnati. OH: south western publishing.

Dessler, G. (2000). Human Resource Management. 8th edition. New Jersey: Prentice Hall International, Inc.

De Waal, A.A. (2007), Strategic Performance Management, a Managerial and Behavioural Approach, Palgrave Macmillan, London.

Epstein, Paul D.” Measuring the performance of public services" Public Productivity Hand Book ed by Marc Holzer, New York, NY: Marcel Dekker inc. 1992.

Franzsen, K. 2003. A critical overview of trends and practices in performance management in the South African higher educational environment. South African Journal of Higher Education, 17(2), 131-138.

http://www.ukessays.com/dissertations/management/performanceappraisal.php\#ixzz2cX13uEvK cited on 26thSeptember,2013.

Langfield-Smith, K. (1997), "Management control systems and strategy: a critical review", Accounting, Organizations and Society, Vol. 22 No. 2, pp. 20732.

Longo, R., (2011), Performance Appraisal V Performance Management, HR Professionals

Marques, J. 2008. It's time employees had more said in evaluating their supervisors. Human Resource Management International Digest, 16(5), 35-37.

Mondy R (2008). Human Resource Management. 10th ed., New Jersey: Prentice-Hall.

Roberts, G. E. (2002). Employee performance appraisal system participation: A technique that works. Public Personnel Management, 31, 333-342

Robert L. Laud, (1984) "Performance Appraisal and Its Link to Strategic Management Development", Journal of Management Development, Vol. 3 Iss: 4, pp.3 - 11

Shambhu Nath Chowdhury (July-Sept, 2008) "Developing Performance Appraisal System for Performance Leadership in Banks". docs.google.com.

Shelley, S. 1999. Diversity of appraisal and performance-related pay practices in higher education. Personnel Review, 28(5/6), 439-454. 
Whitney, K. (1994). Improving group task performance: The role of group goals and group efficacy. Human Performance, 7, 55-78.

Winston \& Creamer. 1997. Performance Appraisal. A Handbook for Staffing Practices in Student Affairs. University of Georgia. [Online] Available: http//www.staffingpractices.soe.vt.edu/perfappraisal.htm Accessed: 20 June 2009.

Y. Zhang ( 2009) “ Performance appraisal for Chinese state-owned banking industry, volume6,issue;3dec2009,page189-20

\section{Copyright Disclaimer}

Copyright reserved by the author(s) 